\title{
Coupling the reproductive period of blue shrimp Litopenaeus stylirostris Stimpson, 1874 (Decapoda: Penaeidae) and sea surface temperature in the Gulf of California
}

\author{
Acoplamiento del periodo reproductivo del camarón azul Litopenaeus stylirostris Stimpson, 1874 \\ (Decapoda: Penaeidae) con la temperatura superficial del mar en el Golfo de California \\ E. Alberto Aragón-Noriega ${ }^{1}$ \\ ${ }^{1}$ Centro de Investigaciones Biológicas del Noroeste (CIBNOR), Unidad Sonora \\ Apartado Postal 349, Guaymas, Sonora 85400, México \\ aaragon04@cibnor.mx
}

Resumen.- Se analizó la relación entre la temperatura superficial del mar (TSM) y la duración del período reproductivo de camarón azul Litopenaeus stylirostris en tres zonas latitudinales del Golfo de California. Se obtuvieron hembras maduras capturadas en las áreas de pesca de la región norte del golfo (Puerto Peñasco), región central (Guaymas) y región sur (Mazatlán). En esas mismas zonas se obtuvo la TSM en un área de aproximadamente $1^{\circ}$ geográfico. El promedio de la TSM en el período de enero de 1983 a diciembre de 2000 mostró un incremento de norte (Puerto Peñasco 22,6 $\pm 0,3^{\circ} \mathrm{C}$ ) a sur (Mazatlán 26,2 $\pm 0,2^{\circ} \mathrm{C}$ ). Las variaciones estacionales entre el mes más frío y el más cálido fueron de $7,8^{\circ} \mathrm{C}$ en Mazatlán y de $11,4^{\circ} \mathrm{C}$ en Puerto Peñasco. El período reproductivo del camarón azul en las inmediaciones de Mazatlán fue de siete meses, mientras que en Guaymas y Puerto Peñasco fue de cinco y cuatro meses, respectivamente. Sin embargo, en las tres regiones el período de máxima actividad reproductiva del camarón, fue de mayo a agosto. En conclusión, aguas más cálidas y con menor variabilidad estacional le permiten al camarón azul reproducirse en un período más prolongado.

Palabras clave: Crustacea, peneidos, madurez, respuesta ambiental, México

\begin{abstract}
Reproductive period of the blue shrimp Litopenaeus stylirostris was analyzed for correspondence to sea surface temperature (SST) in three zones of the Gulf of California. Mature females from fishing areas in the north (Puerto Peñasco), center (Guaymas), and south (Mazatlán), and monthly SST of $1^{\circ}$ geographic rectangular area were examined. Average SST for 1983-2000 increased from Puerto Peñasco $\left(22.6 \pm 0.3^{\circ} \mathrm{C}\right)$ to Mazatlán $\left(26.2 \pm 0.2^{\circ} \mathrm{C}\right)$. Seasonal variations of SST between coldest and warmest months were $7.8^{\circ} \mathrm{C}$ in Mazatlán and $11.4^{\circ} \mathrm{C}$ in Puerto Peñasco. The reproductive period near Mazatlán was seven months a year but in Guaymas and Puerto Peñasco were five and four months a year, respectively. Nevertheless, in the three localities blue shrimp had one period of high reproductive intensity from May through August. In conclusion, warm water and low seasonal variability allow blue shrimp to reproduce in larger periods.
\end{abstract}

Key words: Crustacea, penaeid, maturity, environmental response, Mexico

\section{Introduction}

The very popular hypothesis that relatively constant temperature conditions in tropical seas with high water temperatures year-round was the cause of continuous reproduction in populations of a variety of tropical marine invertebrates has been proved in sicyoniid and caridean shrimp species (Bauer 1992) and other Penaeidae members (da Costa \& Fransozo 2004) but still remains poorly understood in Pacific penaeid shrimp species. Even if it is recognized that the environmental conditions affecting the duration of the spawning season in marine invertebrates, it is necessary a coordinated effort in studying latitudinal variation in reproduction of crustaceans (Sastry 1983, Bauer 1992, Bauer \& Vega 1992, Bauer \& Lin 1994).

Bauer \& Lin (1994) concluded that Trachypenaeus similis and T. constrictus from the Gulf of Mexico display a seasonal spawning pattern at a subtropical- 
temperate latitude $\left(30^{\circ} \mathrm{C}\right)$ restricted to warmer months. But for the same species, da Costa \& Fransozo (2004) found mature females year-round at tropical water $\left(23^{\circ} 20^{\prime} \mathrm{N}\right)$. This is a very good example of how environmental dynamics vary over space and time, in same latitude year-round and in the same month along latitudes, and how these changes affect timing and duration of the reproductive period as proposed by Dall et al. (1990). Also, Leal et al. (2001) found that the inter-annual variability of temperature cause changes in reproductive pattern of a species in the same zone. Those studies suggest (indirectly) that temperature is an important environmental stimulus (proximal factor) responsible for some shrimp’s species (Bauer \& Vega 1992).

Environmental conditions, particularly temperature, require adaptations from marine organisms. If reproduction responds to temperature, caution must be taken into account because the thermal requirements for reproduction often are restricted to a narrow temperature window range separating growth from the reproductive temperature range (Kinne 1970). The optimal temperature for Litopenaeus stylirostris (Stimpson, 1874) was established as $27-29^{\circ} \mathrm{C}$ (Robertson et al. 1991). However, in laboratory, spawning is possible in a range of $23-29^{\circ} \mathrm{C}$ (Aquacop 1979). The preferred temperature of the blue shrimp is $28^{\circ} \mathrm{C}$ (Re et al. 2004). At this temperature, blue shrimp exhibits a steady metabolic rate through a range of salinities ( $\mathrm{Re}$ et al. 2004). Complexity of the Gulf of California ecosystem may account for the greater genetic structure in species that inhabit this marine ecosystem. There is some evidence that shrimp populations are genetically segregated in the Gulf of California (De la Rosa et al. 2000). Differences in environmental conditions could produce different timing of reproduction and may be related to differences in habitat.

For economic and environmental reasons, there are studies dealing with the reproductive period of the blue shrimp (García 1976, Edwards 1978, Mathews 1981, Garduño \& Calderón 1994, Aragón 2005). However, these descriptive studies did not address the relationship between reproductive periods and temperature. Variability of temperature causes changes in the reproductive pattern of brown shrimp Farfantepenaeus californiensis (Holmes 1900) in the Gulf of California (Aragón \& Alcántara 2005). No study is available on the entire area of the Gulf of California for L. stylirostris, but the hypothesis is that blue shrimp's reproductive period must to couple with sea surface temperature (SST). Being a benthic species, the blue shrimp reproduction period could be better correlate with bottom temperature (BT), but satellite allow us to have a larger time series of SST than BT. Alcántara (2005) found a linear relationship between SST and BT been highly correlated $\left(\mathrm{r}^{2}=0.98\right)$. He also made experiments to correlate the satellite SST and in situ SST, in order to support the fact of using satellite SST. This relationship was also highly correlated $\left(r^{2}=0.82\right)$.

Alcántara (2005) results support the use of SST to compare the reproductive period of the blue shrimp in three latitudinal zones in the Gulf of California. It also allows its use to test the hypothesis that when latitude increasing the reproductive period of $L$. stylirostris, is more restricted in time because the months with warmer temperature are also restricted at high latitudes.

The general purpose of this analysis is to contribute testing generalizations of the paradigm about the latitudinal variation in reproduction of shrimp's species, but the particular objective of this study is to find a relationship between the reproductive periods of the blue shrimp with sea surface temperature (SST) in three latitudinal zones in the Gulf of California.

\section{Materials and methods}

\section{Study area}

The Gulf of California is a large marginal sea of considerable oceanographic and meteorological interest because of its different hydrographic and climatic characteristics. Based on these characteristics, I divided the gulf in Northern, Central, and Southern regions (Fig. 1).

The most important landing ports were selected to label each region in the Gulf of California because these are also the main shrimp fishing areas (Magallón 1987). The areas selected for SST data include the port and the capture area.

The northern region has a temperature that oscillates between $10^{\circ} \mathrm{C}$ and $32^{\circ} \mathrm{C}$ from winter to summer. In the central region, the surface temperature shows less marked differences between winter and summer, between $16^{\circ} \mathrm{C}$ and $31^{\circ} \mathrm{C}$. The southern region, which is an extension of the tropical Pacific Ocean, has a 
complex hydrographic structure as a consequence of the confluence of different water masses. On average, the SST decreases from south to the north and seasonal variability increases (Soto et al. 1999).

\section{Data base}

Sea surface temperature (SST) was used from the COADS (Comprehensive Oceanic and Atmospheric Data Set), generated and provided by the NOAA-
CIRES Climate Diagnostics Center. The optimum interpolation (OI) sea surface temperature analysis is produced weekly on a one-degree grid. The analysis uses in situ and satellite SST's plus SST's simulated by sea-ice cover. The OI.v2 analysis is described in Reynolds et al. (2002). Three areas were selected (Fig. 1): Puerto Peñasco (30.5-31.5 $\left.{ }^{\circ} \mathrm{N}, 113.5-114.5^{\circ} \mathrm{W}\right)$, Guaymas $\left(27.5-28.5^{\circ} \mathrm{N}, 110.5-111.5^{\circ} \mathrm{W}\right)$, and Mazatlán $\left(22.5-24.5^{\circ} \mathrm{N}, 106.5-107.5^{\circ} \mathrm{W}\right)$.

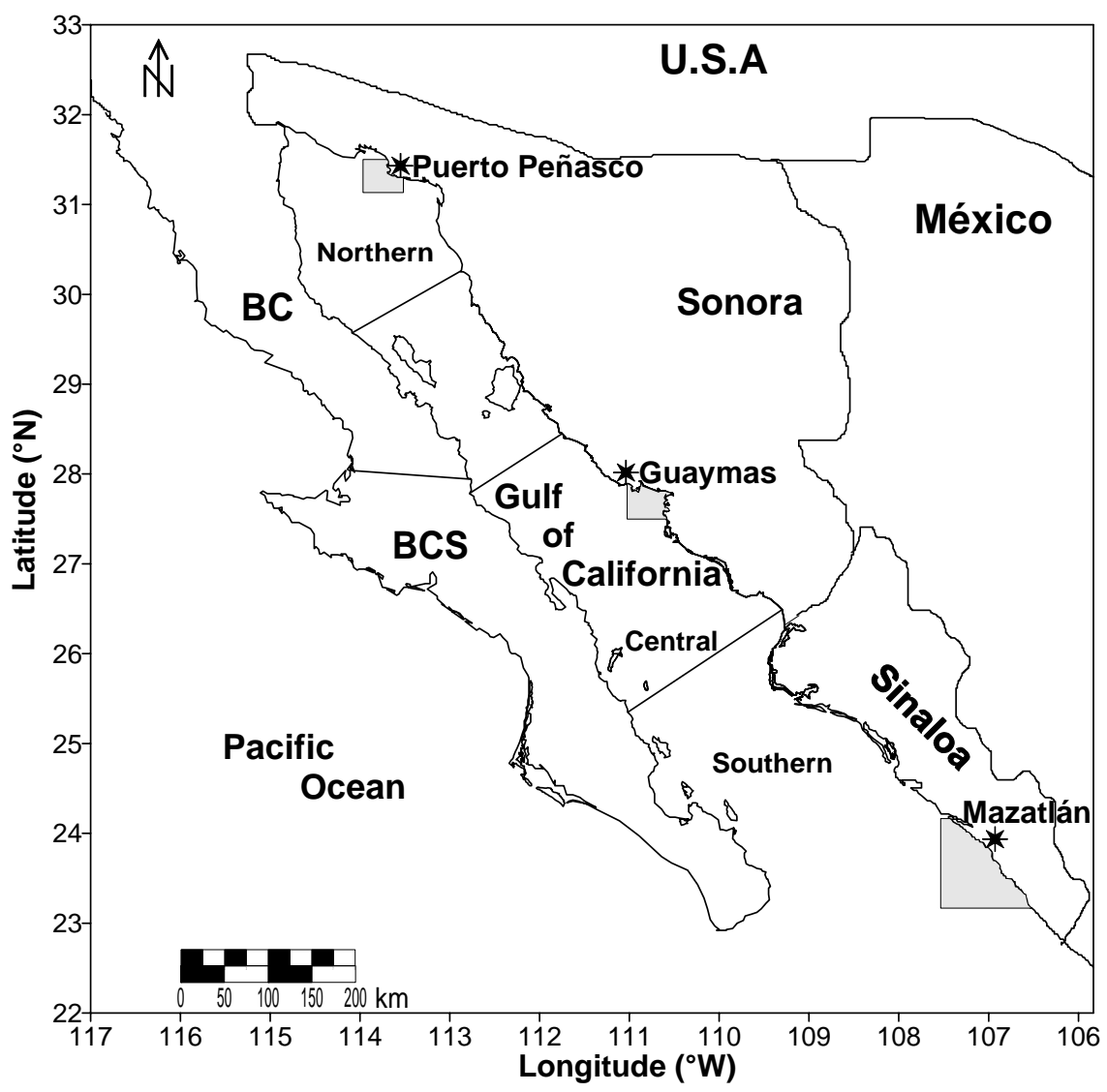

Figure 1

Location of study areas. The map shows the three zones of the Gulf of California (northern, central and south) delimited to study the reproductive period of Litopenaeus stylirostris. The gray areas show the zones where records of sea surface temperature were selected

Localización de las áreas de estudio. El mapa muestra las tres zonas del Golfo de California (norte, central y sur) delimitadas para estudiar el período reproductivo de Litopenaeus stylirostris. Las áreas grises muestran las zonas de donde se seleccionaron los 
Data from these rectangular areas were monthly averages from January 1983 to December 2000. I compared the average of the entire period for each zone, and then compared yearly variations among the three zones by averaging each year's SSTs. Regional climatology was calculated by averaging the monthly SSTs of all the years under study.

Biological data came from samples taken by commercial and research cruises in the regions around Puerto Peñasco, Guaymas and Mazatlán. Two data sources were used. One came from daily packing-plant samplings of commercial captures (September to May) at the three ports, and samplings on board trawlers of the commercial fleet that operated during the closed seasons (June to August) as research cruises, for the period September 1985 to August 2000. The other data set (September 1994 to August 1995) came from samplings on board trawlers of the commercial fleet during the fishing season (September to May) and closed seasons (June to August) at the three ports. Data from 1985-2000 were used to calculate the reproductive period. On board, all captures used gears with the same mesh size (44.45 mm). Captures were taken from 20 to 80 meter depth and from 2 to $5 \mathrm{~km}$ from the shore.

Sex, gonadal maturity and total length (from tip of the rostrum to tip of the telson $\pm 1 \mathrm{~mm}$ ) of the shrimps sampled were determined. The degree of female gonad maturity was determined with the following four phases of a morphochromatic scale (García 1976), involving the ovarian color and volume as follow: immature (I), gonad appearance is transparent, slim in the abdomen; developing (II), gonad more stout, visible nucleus in ovum; mature (III), gonad appearance more stout and coarse in the whole cephalothorax, ovum with vitellus; spent (IV), gonad appearance is flaccid and slim, with a germ cell and residually mature ovum. For this study, the shrimp females were grouped into immature (phases I and II) and mature (phases III and IV) groups. The percent distribution of mature females over the sampling period was determined. It is worthwhile to mention that only mature females were considered to define the reproductive period of Litopenaeus stylirostris inside the Gulf of California. This is supported by the fact that males are mature year-round, in this species (Aragón 2005) as well as in many other penaeid species (Bauer \& Vega 1992, Bauer \& Lin 1994, da Costa \& Fransozo 2004).
The Fisher test, to the 95\% significance level, was performed to compare the mean temperature among the three latitudes studied and among the seasons. When significant differences were found, the Tukey test (Zar 1996) was used. Spearman pairwise rank correlation (Zar 1996) was calculated to test the null hypothesis that there was no correlation between sea surface temperature and percentage of mature females. Linear regression was performed to show the tendency of total months with presence of mature female against mean sea surface temperature and total months with presence of mature female against geographic latitude.

\section{Results}

The SST average (1983-2000) showed a significant difference $\left(\mathrm{F}_{(2,2373)}=215.4, P<0.05\right)$ among the three zones. The SST decreased from Mazatlán (southern region) to Puerto Peñasco (northern region).

Inter-annual SST variability was found in each zone. The variability of SST showed a structure of decreasing northward. Years with low SST were lower at Puerto Peñasco than Mazatlán. And conversely, years with high SST were higher in Mazatlán than Puerto Peñasco (Fig. 2).

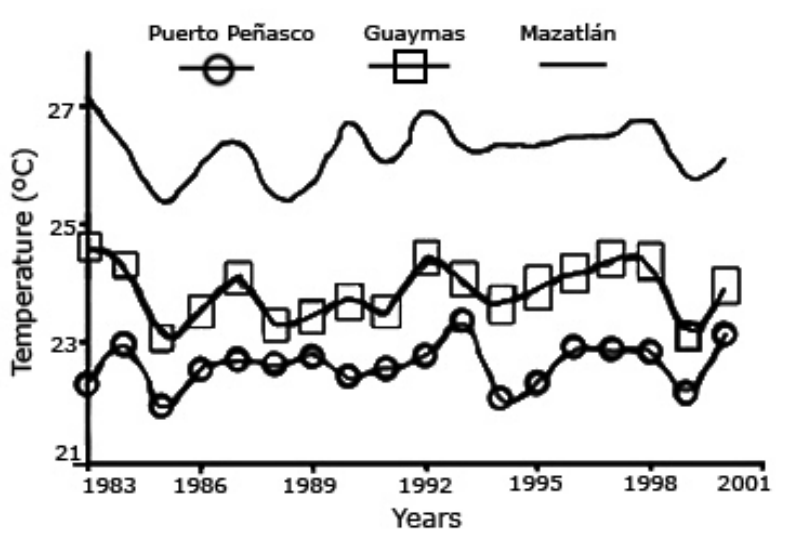

Figure 2

Annual variability of sea surface temperature from 1983 to 2000 in the three zones of the Gulf of California

Variabilidad anual de la temperatura superficial del mar de 1983 a 2000 en las tres zonas del Golfo de California 


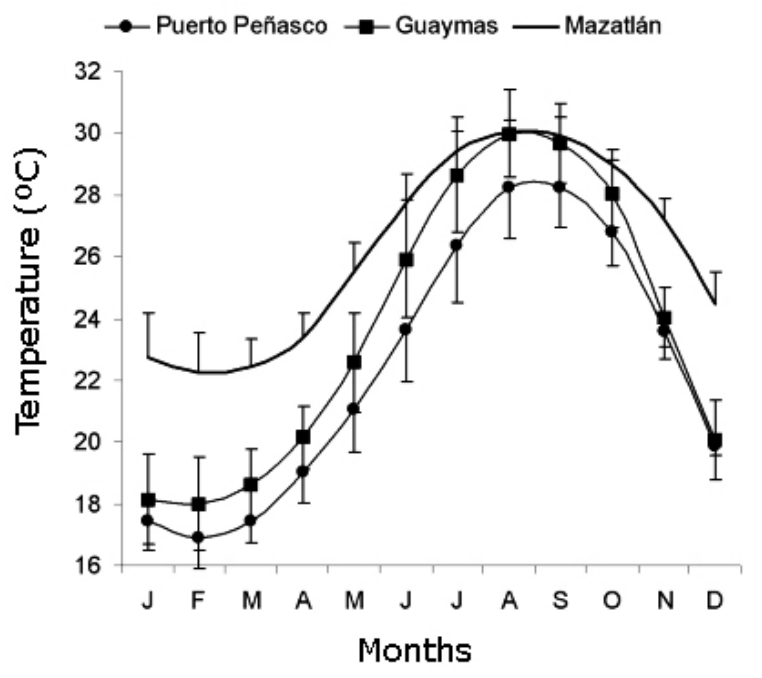

Figure 3

Time series of monthly averages of sea surface temperature from 1983 to 2000 in the three zones of the Gulf of California. Bars represent standard error

Series de tiempo de los promedios mensuales de la temperatura superficial del mar de 1983 a 2000 en las tres zonas del Golfo de California. Las barras representan un error estándar

Seasonal variations were calculated by averaging monthly SSTs for all years (1983-2000). Minimum temperatures occurred in the three regions in February (winter) and maximum temperatures in August-September (summer). There is a marked seasonal variability (Fig. 3). In general, average SST of the three regions differed significantly at all seasons $\left(\underline{F}_{(6,2364)}=54.28, P<0.05\right)$. The exception was a maximum SST in August and September, which were the same in Guaymas and Mazatlán (post hoc Tukey test). However, minimum SST was about $4^{\circ} \mathrm{C}$ higher in Mazatlán than in Guaymas and $5^{\circ} \mathrm{C}$ higher in Mazatlán than in Puerto Peñasco (Fig. 3).

Near Mazatlán, reproduction of blue shrimp was from March to September. Near Guaymas, mature females occurred from April to August, but with a higher percentage from May to July. Near Puerto Peñasco, the reproductive period occurred almost exclusively from May through August (Fig. 4).

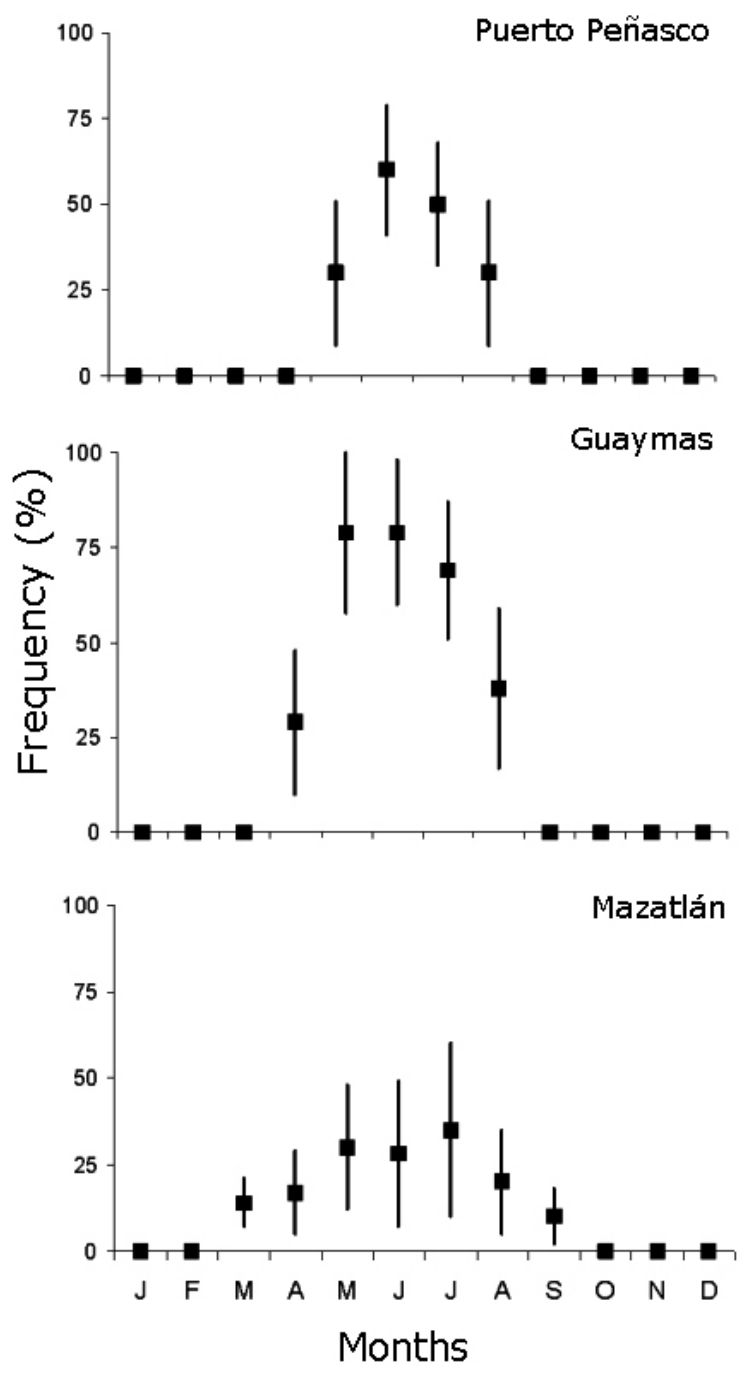

Figure 4

Monthly percent of mature blue shrimp Litopenaeus stylirostris females in the Gulf of California

Porcentaje mensual de hembras maduras de camarón azul Litopenaeus stylirostris en el Golfo de California

The correlation between sea surface temperature and percentage of mature female at the month of sampling was not high but significant $\left(r_{s}=0.369, \mathrm{n}=\right.$ $36, P<0.05)$. The relationship of amount of months with presence of mature females and mean temperature at each latitudinal zone analyzed was highly and 


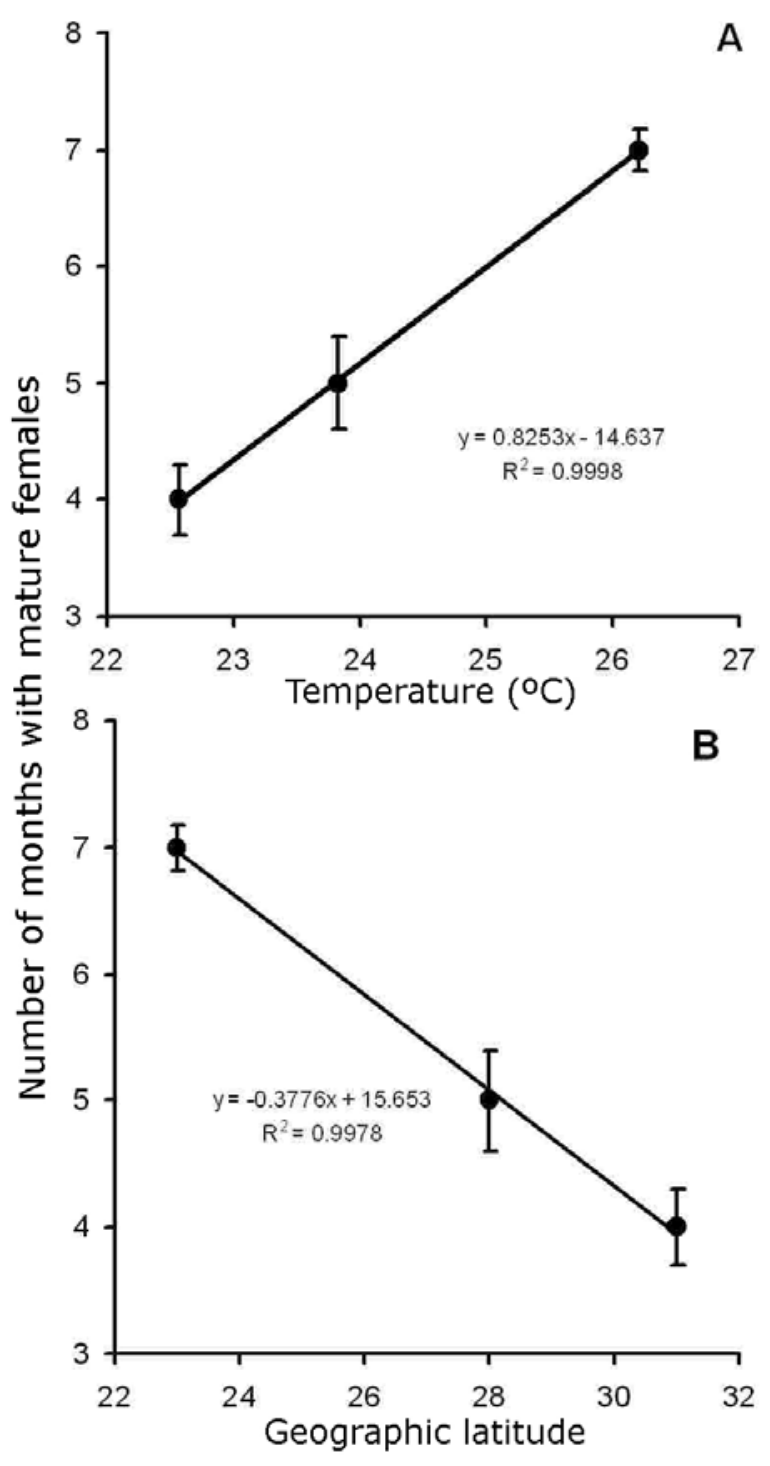

Figure 5

Relationship between number of months with presence of Litopenaeus stylirostris mature females and (A) mean sea surface temperature, and (B) geographic latitude.

$Y=$ number of months with presence of mature females; $\mathbf{R}^{2}=$ Coefficient of determination

Relación entre el número de meses con presencia de hembras maduras de Litopenaeus stylirostris y (A): promedio de temperatura superficial del mar, y (B): latitud geográfica. $\mathrm{Y}=$ número de meses con presencia de hembras maduras; $\mathrm{R}^{2}=$ coeficiente de determinación positively related (Fig. 5A). On the contrary, the relationship with geographic latitude was highly but negatively related (Fig. 5B).

\section{Discussion}

The classical paradigm of continuous reproduction in the tropics and seasonal reproduction at higher latitudes, increasingly restricted in time with an increase in latitude, is supported from the results of this study. The reproductive period of blue shrimp $L$. stylirostris, determined by the percent of mature females, is different depending on the SST of the area. In the south, reproduction is seven months long. In the north, reproduction occurs during a roughly four-month warm period.

The most important physical oceanographic variable that influences biology aims thought to be SST (Bakun 1996). Several fisheries scientists noted the use of climate information (e.g. SST) in stock assessment (primarily to analyze catchability and estimate recruitment) and ecosystem models, emphasizing that climate information is not only useful to fishery managers, but plays a crucial role in research as well (Bakun 1996).

The reproductive biology of penaeid shrimps is closely linked to water temperature as a proximal factor (Sastry 1983, Bauer 1992, Bauer \& Vega 1992, Bauer \& Lin 1994, da Costa \& Fransozo 2004). Differences in time of maturation in relation to environmental optima may become established during development, and cause shrimp populations to become reproductively isolated (Aubert \& Lightner 2000). These authors found a genetic differentiation between Litopenaeus stylirostris populations along the Gulf of California and concluded that the oceanographic characteristics of the Gulf (included temperature) could act as isolating mechanisms resulting in reproductive isolation.

A previous study on the effects of SST to reproductive periods of brown shrimp, Farfantepenaeus californiensis includes data analysis only from the central region (Leal et al. 2001). They found that interannual variations magnify seasonal variations, with the periods of maximum reproduction corresponding to the warmer months. Findings in the present study showed that a strong gradient from south to north becomes apparent between the SST and the length of the 
reproductive period of the blue shrimp, similar to the effects of SST on reproductive period of brown shrimp reported from the entire Gulf of California (Aragón \& Alcántara 2005).

The general tendency of the ocean in its annual and daily variation in temperature is smallest in the tropics, increases in the mid-latitudes, and decreases again near the poles (Halsband 2001). Soto et al. (1999) analyzed SSTs in the Gulf of California from 14 years of satellite images (1983-1996) to describe monthly, semi-annual, annual, and inter-annual variability in terms of averages and seasonality. Three regions were defined (see Fig. 1), matching them with the most important fishery areas and their homeports. The delineation of the three regions closely agrees with the findings of others (Soto et al. 1999). The same pattern proposed by these authors in the Gulf of California and general tendencies in oceans was found. The focus was to define the relationship between SSTs and blue shrimp reproductive periods in the three regions of the Gulf. It is worthwhile to mention that only mature females were considered to define the reproductive period of Litopenaeus stylirostris inside the Gulf of California. This is supported by the fact that males are mature year-round, in this species (Aragón 2005) as well as in many other penaeid species (Bauer \& Vega 1992, Bauer \& Lin 1994, da Costa \& Fransozo 2004). A thermal requirement for reproduction of Litopenaeus stylirostris is $27-29^{\circ} \mathrm{C}$ (Robertson et al. 1991). This temperature was found, in the Gulf of California from June to September at the three localities matching with the higher percentage of mature female as well. The widest range $\left(23-29^{\circ} \mathrm{C}\right)$ reported for reproduction of this species (Aquacop 1979) is present in Mazatlán almost year round, but mature females were found from March through September.

If the optimal reproductive temperature for a species is known, additional factors, such as food availability, play an important role (Halsband \& Hirche 2001). Populations must spawn in favorable habitats (shelter and enough food) for their offspring. Penaeid shrimp spend their adult life and spawning stage offshore. Eggs hatch $14 \mathrm{~h}$ after spawning and the larvae pass quickly though a series of planktonic stages: nauplius (feeds on its egg sac), protozoea, and mysis, and finally after 10-14 days, they migrate as postlarvae to coastal and estuarine waters (García \& Le Reste 1981). Explanations for this behavior have been proposed. Wickins (1976) summarized the mechanisms by which postlarvae penetrate estuaries. As the tide rises, a salt wedge moves inward along the bottom of the estuary and the postlarvae leave the bottom in response to increased salinity. They are carried up the estuary in the saline water (fresh water flows seaward at the surface), and when the tide reaches its peak and begins to ebb, the postlarvae settle to the bottom in response to the decreased salinity. Other authors suggest that the postlarvae stage get into estuaries following attractants in the seaward-bound water (Benfield \& Aldrich 1992).

Garduño \& Calderón (1994) proposed that the SST is a signal of food availability for shrimp in the southern part of the Gulf and speculated that this is the "switch" for spawning because Litopenaeus stylirostris shrimp, like other related species, is migratory with separate habitats for juvenile and adult populations (Riera et al. 2000, Gillanders et al. 2003).

If detritus from the mainland is an important component of the food supply (Riera et al. 2000), and enters the ocean with streamflow, it is not surprising that the southern area (subtropical) has the highest food supply because the area has the largest streamflow from greater rainfall (Brito et al. 2003). Arid and semi-arid climate coastal lagoons in the north $\left(24-28^{\circ} \mathrm{N}\right)$ and wetdry tropical climate lagoons occur in the south (Mazatlán). This has influence on food available for shrimp postlarvae as showed by Valdés (1994) whom demonstrated that these lagoons are under influence of different seasonal patterns of nutrient supply and phytoplankton production. In spite of the role of nutrients, summer temperature is still the signal for spawning in the blue shrimp Litopenaeus stylirostris in the northernmost part of the gulf after damming of the Colorado River and freshwater flow and nutrient supply become null (Aragón \& Calderón 2000, 2001, Aragón \& García 2002).

In copepods reproductive studies it was showed that temperature controlled egg production if food conditions were not limiting (Halsband \& Hirche 2001). In the case of the blue shrimp in the Gulf of California, it is difficult to associate food availability with reproductive activity. The areas of focus are separated by variations in phytoplankton pigment concentrations (Santamaría et al. 1994). These authors concluded that shrimp are abundant in the eastern coast of the gulf (mainland coast) because of the kind of pigment in the area. If that 
idea is correct, then temperature is a more important controlling factor during spawning than food availability.

Inter-annual variations in temperature caused changes in reproductive behavior of brown shrimp within a region (Leal et al. 2001). It would also be expected that this temperature variations along the gulf causes change in reproductive timing of blue shrimp among regions.

Variability in SST in the Gulf of California was delineated. Ecological variables (stream flow to the Gulf of California, pigment concentration in the gulf) and physiological response of blue shrimp was also discussed. Temperature variations appear to be the most significant variable affecting reproductive activity of blue shrimp in the Gulf of California.

\section{Acknowledgments}

This study was supported by CIBNOR funds. C. Pacheco and J.J. Bautista of CIBNOR's Modeling and Forecasting Fishing Laboratory improved and provided SST data. A.R. Garcia at National Fisheries Institute, Pacific Shrimp Program, provided the biological data. Three anonymous reviewers improved significantly the actual version of this manuscript.

\section{Literature cited}

Alcántara RE. 2005. Índice de producción de huevos, reclutamiento reproductor y distribución de la biomasa de camarón azul Litopenaeus stylirostris en el frente costero de Agiabampo, Sonora-Sinaloa, México. Tesis de maestría CICIMAR. La Paz, B.C.S. México. 75 pp.

Aquacop. 1979. Penaeid reared brood stock: closing the cycle of $P$. monodon, $P$. stylirostris and $P$. vannamei. Proceedings of the World Mariculture Society 10: 445452.

Aragón NEA. 2005. Reproductive output of the blue shrimp, Litopenaeus stylirostris (Decapoda: Penaeidae) in the Gulf of California coast at Agiabampo, Sonora-Sinaloa, México. Journal of Shellfish Research 24(2): 597-601.

Aragón NEA \& E Alcántara. 2005. Influence of sea surface temperature on reproductive period and size at maturity of the brown shrimp (Farfantepenaeus californiensis) in the Gulf of California. Marine Biology 146(2): 373-379.

Aragón NEA \& LE Calderón. 2000. Does damming the Colorado River affect the nursery area of blue shrimp Litopenaeus stylirostris (Decapoda: Penaeidae) in the
Upper Gulf of California? Revista de Biología Tropical 48(4): 867-871.

Aragón NEA \& LE Calderón. 2001. Age and growth of shrimp postlarvae in the upper Gulf of California. Journal of Ichthyology and Aquatic Biology 4(3): 99-104.

Aragón NEA \& AR García. 2002. Reclutamiento de postlarvas de camarón azul Litopenaeus stylirostris (Stimpson, 1871) a condiciones antiestuarinas provocadas por actividades antropogénicas. Hidrobiológica 12(1): 3746.

Aubert H \& VV Lightner. 2000. Identification of genetic populations of the Pacific blue shrimp Penaeus stylirostris of the Gulf of California, Mexico. Marine Biology 137: 875-885.

Bakun A. 1996. Patterns in the ocean: Ocean processes and marine population dynamics, 323 pp. University of California Sea Grant, in cooperation with Centro de Investigaciones Biológicas del Noroeste, La Paz, México.

Bauer RT. 1992. Testing generalizations about latitudinal variation in reproduction and recruitment patterns with sicyoniid and caridean shrimp species. Invertebrate Reproduction and Development 22(1-3): 193-202.

Bauer RT \& RLW Vega. 1992. Pattern of reproduction and recruitment in two sicyoniid species (Decapoda: Penaeiodea) from tropical seagrass habitat. Journal of Experimental Marine Biology and Ecology 161(2): 223240.

Bauer RT \& J Lin. 1994. Temporal patterns of reproduction and recruitment in populations of the penaeid shrimps Trachypenaeus similis (Smith) and T. constrictus (Stimpson) (Crustacea: Decapoda) from the Northcentral Gulf of Mexico. Journal of Experimental Marine Biology and Ecology 182(2): 205-222.

Benfield MC \& DV Aldrich. 1992. Attraction of postlarval Penaeus aztecus Ives and $P$. setiferus (L.) (Crustacea: Decapoda: Penaeidae) to estuarine water in a laminarflow choice chamber. Journal of Experimental Marine Biology and Ecology 156: 39-52.

Brito CL, S Díaz, CA Salinas \& AV Douglas. 2003. Reconstruction of long-term winter streamflow in the Gulf of California continental watershed. Journal of Hydrology 28: 39-50.

da Costa C \& RA Fransozo. 2004. Reproductive biology of the shrimp Rimpenaeus constrictus (Decapoda, Penaeidae) in the Ubatuba of Brazil. Journal of Crustacean Biology 24(2): 274-281.

Dall W, BJ Hill, PC Rothlisberg \& DJ Staples. 1990. The biology of the Penaeidae. In: Blaxter JHS \& AJ Southward (eds), Advances in Marine Biology 27: 1-489. Academic Press, London. 
De la Rosa VJ, R Escobar, F Correa, M. Maqueda, J de la Torre. 2000. Genetic structure of two commercial penaeids (Penaeus californiensis and $P$. stylirostris) from the Gulf of California, as revealed by allozyme variation. Fishery Bulletin 98: 674-683.

Edwards RRC. 1978. The fishery and fisheries biology of the penaeid shrimp on the Pacific Coast of Mexico. Oceanography Marine Biology Annual Review 16: 145180

García S \& L Le Reste. 1981. Life cycles, dynamics, explotation and management of coastal penaeid shrimp stocks. FAO Fisheries Technical Paper 203: 1-215.

García GM. 1976. Fecundidad del camarón café Penaeus californiensis y del camarón azul Penaeus stylirostris Puerto Peñasco y Guaymas, Sonora. In: Instituto Nacional de Pesca, (eds). Memorias del Simposio sobre biología y dinámica poblacional de camarones 1: 131-139. Subsecretaria de Pesca, Guaymas, Sonora, México.

Garduño AH \& JA Calderón. 1994. Abundancia y maduración sexual de hembras de camarón (Penaeus spp.) en la costa sur de Sinaloa, México. Revista de Investigaciones Científicas, Universidad Autónoma de Baja California Sur. Serie Ciencias Marinas 1: 27-34.

Gillanders BM, KW Able, J Brown, DB Eggleston \& PF Sheridan. 2003. Evidence of connectivity between juvenile and adult habitats for mobile marine fauna: an important component of nurseries. Marine Ecology Progress Series 247: 281-295.

Halsband LC. 2001. Temperature impact on reproduction and development on congener marine copepods - a key to distribution patterns? Ph D Thesis, University of Oldenburg, Germany, 140 pp.

Halsband C \& HJ Hirche. 2001. Reproductive cycles of dominant calanoid copepods in the North Sea. Marine Ecology Progress Series 209: 219-229.

Kinne O. 1970. Marine ecology: A comprehensive, integrated treatise on life in the oceans and coastal waters, 1 Environmental factors, $681 \mathrm{pp}$. Wiley, New York.

Leal GA, J López, EA Chávez, S Hernández \& F Méndez. 2001. Inter-annual variability of reproductive period of the brown shrimp, Farfantepenaeus californiensis (Holmes, 1900) (Decapoda, Natantia). Crustaceana 74(9): 839-851.
Magallón BFJ. 1987. The Pacific shrimp fishery of México. CalCOFI Reports 27: 43-52.

Mathews CP. 1981. A review of the North American penaeid fisheries, with particular reference to Mexico. Kuwait Bulletin of Marine Science 2: 325-409.

Re AD, F Díaz, E Sierra \& S Gómez. 2004. Consumo de oxígeno, excreción de amonio y capacidad osmorreguladora de Litopenaeus stylirostris (Stimpson) expuesto a diferentes combinaciones de temperatura y salinidad. Ciencias Marinas 30(3): 443-453.

Reynolds RW, NA Rayner, TM Smith, DC Stokes \& W Wang. 2002. An improved in situ and satellite SST analysis for climate. Journal of Climate 16: 1609-1625.

Riera P, PA Montagna, RD Kalke \& P Richard. 2000. Utilization of estuarine organic matter during growth and migration by juvenile brown shrimp Penaeus aztecus in a South Texas estuary. Marine Ecology Progress Series 199: $205-216$

Robertson L, W Bray \& A Lawrence. 1991. Reproductive response of Penaeus stylirostris to temperature manipulation. Journal of the World Mariculture Society 22(2): 109-117.

Santamaría E, S Alvarez \& FE Müller. 1994. Gulf of California biogeographic regions based on coastal zone color scanner imagery. Journal of Geophysical Research 99: 7411-7421.

Sastry AN. 1983. Ecological aspect of reproduction. In: Vernberg FJ \& WB Vernberg (eds), The biology of Crustacea: environment adaptations. Pp. 179-270. Academic Press, New York.

Soto MS, SG Marinone \& A Parés. 1999. Time and spatial variability of sea surface temperature in the Gulf of California. Ciencias Marinas 25(1): 1-30.

Valdés HJE. 1994. Variaciones diarias de temperatura, salinidad, oxígeno disuelto y clorofila a, en una laguna hipersalina del Golfo de California. Ciencias Marinas 20(2): 123-137.

Wickins JF. 1976. Prawn biology and culture. Oceanography and Marine Biology Annual Review 14: 435-507.

Zar JH. 1996. Biostatistical analysis. 662 pp. $3^{\text {rd }}$ edition. Prentice Hall, Upper Saddle River, New Jersey. 